\title{
Daur Ulang Limbah Gel Agarose untuk Efisiensi Reagen Elektroforesis
}

\author{
Rumbiwati ${ }^{1}$, Joko Trimuratno \\ 'Laboratorium Parasitologi Fakultas Kedokteran, Kesehatan Masyarakat dan Keperawatan \\ UGM, Jl. Farmako, Sekip, Yogyakarta, rumbiwati@gmail.com.
}

Submisi: 12 September 2021; Penerimaan: 30 Desember 2021

\begin{abstract}
ABSTRAK
Penggunaan gel agarose dalam penelitian molekuler untuk melihat DNA dengan elektroforesis umumnya hanya digunakan sekali pakai. Sementara itu agarose merupakan bahan mahal dan perlu waktu lama dalam pemesanan. Pada penelitin ini peneliti mencoba mendaur ulang limbah gel agarose untuk digunakan kembali dalam elektroforesis agar penggunaan agarose lebih efisien.

Ada beberapa metode daur ulang gel agarose, diantaranya dioven dengan suhu $60^{\circ} \mathrm{C}$, gel akan berbentuk kering, dihaluskan dan ditimbang kembali jika akan digunakan. Metode lain gel disimpan dalam freezer hingga menjadi es. Perbedaan penelitian ini dengan penelitian yang lain adalah metode daur ulang gel agarose ini lebih sederhana. Gel agarose daur ulang disimpan dalam plastik, dimasukkan dalam kulkas suhu $4^{\circ} \mathrm{C}$. Jika akan digunakan kembali gel agarose dipotong kecil-kecil dimasukkan dalam elermeyer, dipanaskan dengan suhu tinggi sekitar $190^{\circ} \mathrm{C}$ menggunakan microwave dalam waktu 2 menit. Metode daur ulang gel agarose ini dinilai lebih efisien karena tidak perlu lagi menimbang agarose dan menghemat pemakaian agarose baru serta mengurangi limbah laboratorium

Berdasarkan hasil penelitian dari 5 kali daur ulang gel agarose, elektroforesis dengan gel agarose daur ulang 1 kali menunjukkan Gambar paling bagus yaitu pita DNA hasil PCR jelas dan sama dengan Gambar elektroforesis menggunakan gel agarose baru (kontrol). Daur ulang ke 5 menunjukkan visualisasi Gambar elektroforesis yang tidak jelas, sehingga dapat disimpulkan daur ulang gel agarose hanya bisa dilakukan 1 hingga 4 kali ulangan. Hal ini membuktikan bahwa daur ulang gel agarose dapat digunakan kembali untuk elektroforesis dengan hasil yang bagus, sesuai target yang diinginkan.
\end{abstract}

Kata kunci: Daur ulang, gel agarose, elektroforesis.

\section{PENDAHULUAN}

Penelitian molekuler tentang
diagnose suatu penyakit saat ini
berkembang dengan pesat. Penelitian ini menggunakan bahan baku DNA ataupun RNA hasil isolasi, dan selanjutnya sampel diuji dengan metode PCR maupun qPCR. Uji sampel dengan metode PCR, untuk melihat gen target menggunakan gel agarose yang disebut dengan elektroforesis (Sudjadi, 2008). Bahan agarose ini merupakan bahan yang cukup mahal harganya dan perlu waktu lama dalam pemesanan. Gel agarose untuk elektroforesis biasanya hanya digunakan sekali dan setelah itu dibuang. Dalam penelitin ini peneliti mencoba mendaur ulang gel agarose untuk dapat digunakan kembali dalam elektroforesis agar penggunaan agarose lebih efisien. Gel agarose yang sudah tidak dipakai dipanaskan kembali dengan microwave dan dicetak ulang dengan penambahan pewarna seperti floro few sebagai pewarna DNA. Untaian DNA akan rusak pada suhu $190^{\circ} \mathrm{C}$, (Liebert, 2013). Diharapkan dengan pemanasan 
yang tinggi pada microwave untaian DNA pada gel agarose daur ulang telah rusak sehingga akan menghasilkan gel agarose baru dan siap dipakai kembali untuk elektroforesis tanpa merubah hasil yang didapat.

Tujuan dari penelitian ini adalah memanfaatkan daur ulang limbah gel agarose untuk efisisensi reagen elektroforesis, mengetahui hingga berapa kali daur ulang limbah gel agarose dapat digunakan dan mengetahui daur ulang limbah gel agarose yang paling baik untuk efisiensi regaen elektroforesis.

\section{METODE PENELITIAN}

\section{Jenis Penelitian}

Penelitian ini merupakan penelitian observasional diskriptif yaitu menyimpulkan hasil dari visualisasi Gambar elektroforesis yang dihasilkan.

\section{Metode Penelitian}

Alat : cetakan agarose, chamber elektroforesis, microwave, sentrifuse, termo cycler, UV transiluminator, nano drop, mikro pipet. Bahan : agarose, floro fiew, TBE 1x, akuadest, kit DNA, primer gen Ace-1 Forward 5'CGATAACGAATGGGGAACG-3' dan Ace-1 Reverse 5'TCAGAGGCTCACCGAACACA-3',

gotaq green, sampel nyamuk, tip kuning, tip biru, tip putih, tube $1,5 \mathrm{ml}$,tube $0,2 \mathrm{ml}$. Cara kerja: Menyiapkan alat dan bahan. Mengisolasi DNA dari sampel nyamuk. Sampel nyamuk (Aedes sp.) sekitar 20 ekor diisolasin DNAnya menggunakan KIT DNA tissue merk Genaid, kemudian hasil isolasi diukur DNAnya menggunakan nano drop. DNA diamplifikasi dengan gen Ace-1 menggunakan primer Ace-1 F dan Ace-1 $R$. Total volume yang digunakan untuk amplifikasi sebanyak $30 \mu$, yang terdiri atas DNA template $2 \mu \mathrm{l}$, primer $10 \mu \mathrm{M} 2 \mu \mathrm{l}$,

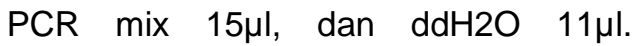

Tahapan PCR dilakukan dengan denaturasi pada suhu $94^{\circ} \mathrm{C}$ selama 3 menit, diikuti oleh 35 siklus pada suhu $94^{\circ} \mathrm{C}$ selama 2 menit, suhu $58^{\circ} \mathrm{C}$ selama 1 menit, $72^{\circ} \mathrm{C}$ selama 2 menit. Final extension pada $72^{\circ} \mathrm{C}$ selama 7 menit, (Grigoraki et al., 2015). Tahap berikutnya adalah pembuatan gel agarose untuk elektroforesis.

Pada penelitian ini pembuatan gel agarose dilakukan dengan tahap sebagai berikut: Pertama membuat gel agarose menggunakan agarose baru $2 \%$ dengan cara menimbang agarose 2 gram, memasukkan agarose dalam elemeyer. Menambahkan TBE 1x dalam agarose sebanyak $100 \mathrm{ml}$, Agarose dipanaskan dengan microwave selama 2 menit sampai larut sempurna. Floro fiew konsentrasi $10 \mathrm{mg} / \mathrm{ml}$ ditambahkan sebanyak $5 \mu \mathrm{l}$. Gel agarose dicetak pada cetakan agarose, ditunggu sekitar 30 menit sampai gel agarose dingin dan siap digunakan. Tahap elektroforesis, berfungsi untuk melihat hasil amplifikasi DNA dengan PCR, (Fatchiyah, at al., 2011). Gel agarose dimasukkan pada chamber elektroforesis. Ditambahkan TBE $1 x$ sampai semua gel agarose tergenang, mengatur voltase pada angka 100V. Running gel selama 30 menit. Agarose bekas selanjutnya disimpan di kulkas suhu $4^{\circ} \mathrm{C}$ supaya tidak kering sebelum di daur ualng. Penyimpana agarose bisa sampai 3-6 bulan.

Hasil elektroforesis dilihat di bawah UV transiluminator dan akan menunjukkan pita pada posisi 540bp. Daur Ulang Gel agarose (tahap perlakuan penelitian). Agarose bekas elektroforesis dikeluarkan dari kulkas ditunggu sampai suhu kamar. Agarose dari simpanan yang masih berbentuk batangan dipotong kecil-kecil, dan dimasukkan dalam elenmeyer sampai volume $100 \mathrm{ml}$. Untuk mempertahankan kondisi agarose tetap 2\% ditambahkan TBE $1 \mathrm{x}$ sebanyak $1 \mathrm{ml}$. Agarose 
dipanaskan pada microwave selama 2 menit. Floro fiew ditambahkan sebanyak 2,5 $\mathrm{\mu l}$. Gel agarose dicetak pada cetakan agarose, ditunggu sekitar 30 menit sampai gel agarose dingin dan siap digunakan. Tahap ini merupakan daur ulang agarose I. Agarose bekas selanjutnya disimpan di kulkas suhu $4^{\circ} \mathrm{C}$ supaya tidak kering sebelum di daur ulang yang II dan seterusnya. Pada penelitian ini daur ulang dilakukan sebanyak 5 kali (sampai hasil elektroforesis tidak kelihatan). Elektroforesis dilakukan menggunakan sampel DNA yang sama dengan sebelumya dan gel agarose hasil daur ulang. Hasil elektroforesis dilihat di bawah UV transiluminator dan dibandingkan hasil elektroforesis menggunakan gel agarose baru dengan hasil elektroforesis menggunakan agarose daur ulang menunjukkan pita pada posisi yang sama yaitu 540bp.

\section{HASIL DAN PEMBAHASAN}

Hasil pengukuran konsentrasi DNA dengan nano drop dapat dilihat pada Tabel 1. Pada penelitian ini dilakukan 6 kali isolasi DNA dengan sampel yang berbeda sebagai ulangan perlakuan untuk dilihat hasil elektroforesisnya. Tiap sampel terdiri dari 20 ekor nyamuk. Dilihat dari hasil pengukuran konsentrasi DNA pada table 1 menunjukkan bahwa isolasi DNA dari sampel nyamuk berhasil dengan baik. Terbukti kemurnian DNA pada masingmasing sampel berkisar antara 1,7971,987. Artinya kemurnian DNA yang didapat masih dalam kisaran yang diinginkan yaitu 1,7-2. Konsentrasi DNA yang di dapat cukup tinggi dari masingmasing sampel berkisar antara 98,172$178,816 \mathrm{ng} / \mu \mathrm{l}$. Konsentrasi ini cukup untuk mendeteksi suatu gena dengan metode PCR yang hanya membutuhkan DNA dengan konsentrasi sekitar 10$50 \mathrm{ng} / \mu \mathrm{l}$
Tabel 1. Hasil pengukuran konsentrasi DNA.

\begin{tabular}{ccc}
\hline $\begin{array}{c}\text { No } \\
\text { Sampel }\end{array}$ & A260/A280 & $\begin{array}{c}\text { Konsentrasi } \\
\text { DNA(ng/ul) }\end{array}$ \\
\hline 1 & 1,871 & 102,539 \\
2 & 1,926 & 150,328 \\
3 & 1,987 & 110,218 \\
4 & 1,848 & 98,172 \\
5 & 1,892 & 120,572 \\
6 & 1,797 & 178,816 \\
\hline
\end{tabular}

DNA hasil isolasi di PCR menggunakan mesin PCR dengan primer gen Ace-1 Forward 5'CGATAACGAATGGGGAACG-3' dan Ace-1 Reverse 5'TCAGAGGCTCACCGAACACA-3' yaitu gen resistensi yang terdapat pada nyamuk Aedes aegypti. Hail PCR dielektroforesis menggunakaan gel agarose baru sebagai kontrol perlakuan dan gel agarose daur ulang sebagai perlakuan untuk melihat pita DNA pada target 540bp. Daur ulang gel agarose dilakukan sebanyak 5 kali sampai hasil elektroforesis tidak terbentuk pita yang diinginkan. Hasil elektroforesis dilihat di bawah UV transilluminator. Hasil elektroforesis gel agarose baru dan daur ulang dari penelitian ini dapat dilihat pada Gambar 1.

Pada Gambar 1 dapat dilihat berdasarkan visualisasi elektroforesis ada perbedaan antara Gambar elektroforesis menggunakan gel agarose baru sebagai kontrol (a) dengan gel agarose daur ulang sebagai perlakuan (b,c,d,e,f). Dari 5 kali daur ulang gel agarose, daur ulang ke 5 menunjukkan visualisasi Gambar elektroforesis yang tidak jelas, sehingga dapat disimpulkan daur ulang gel agarose hanya bisa dilakukan 1 hingga 4 kali ulangan. Elektroforesis dengan gel agarose daur ulang 1 kali menunjukkan Gambar paling bagus yaitu pita DNA hasil PCR jelas dan sama dengan Gambar elektroforesis menggunakan gel agarose baru (kontrol). Hal ini membuktikan bahwa daur ulang gel agarose dapat digunakan 
kembali untuk elektroforesis dengan hasil yang bagus, sesuai target yang diinginkan. Pita DNA yang terdapat dalam gel agarose akan terdegradasi ketika gel agarose daur ulang dipanaskan dengan suhu tinggi sekitar $190^{\circ} \mathrm{C}$. (Liebert ,2013). Pada metode daur ulang ini pemanasan dilakukan dengan microwave dalam waktu 2 menit.
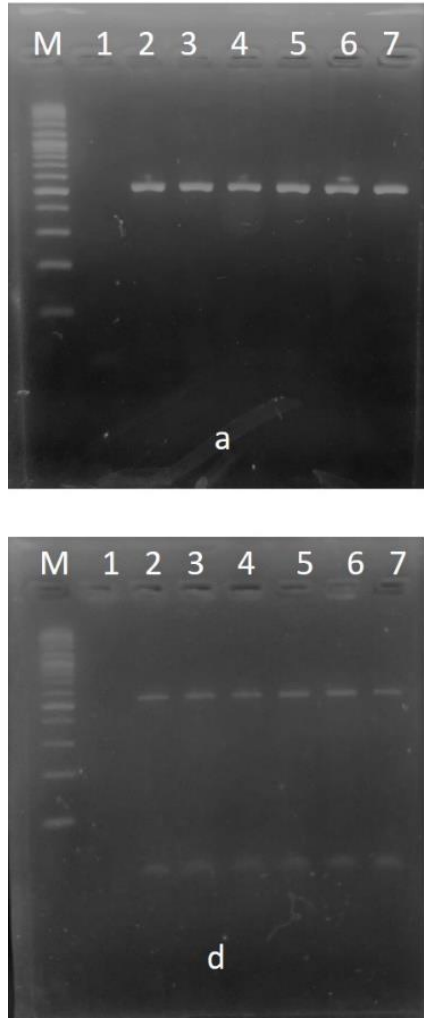
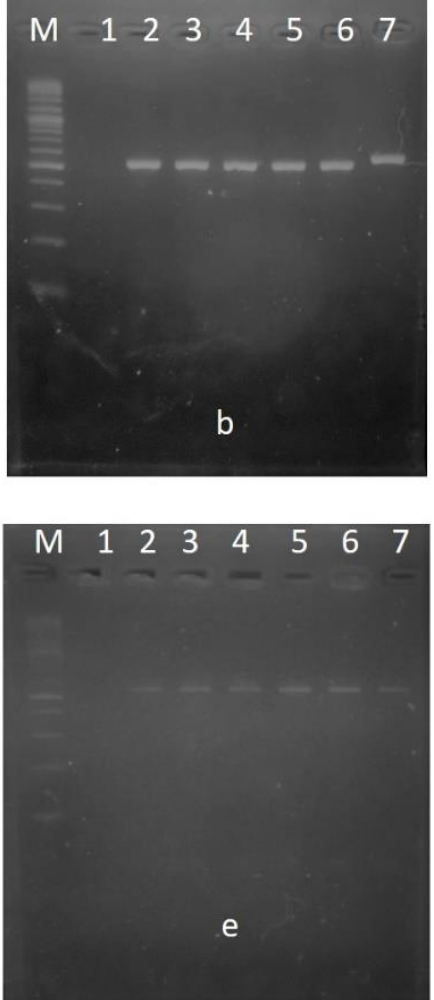

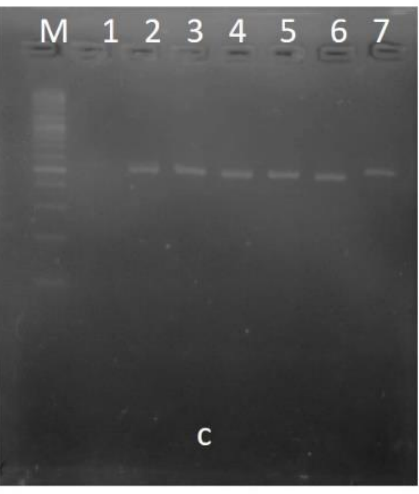

$\begin{array}{llllllll}M & 1 & 2 & 3 & 4 & 5 & 6 & 7\end{array}$

Gambar 1: a: Elektroforesis agarose baru (kontrol), b: Elektroforesis daur ulang agarose 1 kali, c: Elektroforesis daur ulang agarose 2 kali, d: Elektroforesis daur ulang agarose 3 kali, e: Elektroforesis daur ulang agarose 4 kali, f: Elektroforesis daur ulang agarose 5 kali, M:Marker DNA. 1:Kontrol negatif PCR, (2-7 sampel nyamuk)

Daur ulang gel agarose pada penelitian ini hanya bisa dilakukan sampai 4 kali ulangan. Terbukti pada daur ulang gel agarose ulangan ke 5 menunjukkan visualisasi Gambar elektroforesis yang tidak jelas. Hal ini kemungkinan disebabkan karena sudah banyak sisa-sisa DNA pada gel agarose yang di elektroforesis sebelumnya. Sisasisa DNA ini sebagian ikut berpendar yang mengakibatkan fragmen DNA yang dielektroforesis menjadi tidak jelas, (Triwibowo, 2009).

Penelitian tentang metode daur ulang gel agarose pernah dilakukan sebelumnya dengan cara mengeringkan gel agarose menggunakan oven suhu $60^{\circ} \mathrm{C}$. Gel agarose akan berbentuk kering seperti serpihan kertas, selanjutnya serpihan ini dihancurkan sampai menjadi serbuk dan digunakan kembali seperti agarose baru sesuai konsentrasi yang diinginkan dengan menambahkan larutan buffer. (Palacious at al., 2000). Penelitian serupa juga pernah dilakukan yaitu daur ulang gel agarose dengan cara gel agarose diletakkan dalam plastik dan dimasukkan dalam freezer selama 24 jam sampai menjadi es. Di dalam freezer gel akan 
menjadi keras dan kering. Gel dapat digunakan kembali dengan cara gel dikeluarkan dari freezer, dipotong kecilkecil dibiarkan pada suhu ruang dan dipanaskan kembali tanpa menambahkan buffer di dalamnya. Pembekuan gel agarose dapat menghilangkan konsentrasi etidium bromid yang bersifat toksik (racun). (Sasagawa, 2018).

Perbedaan penelitian ini dengan penelitian yang lain adalah metode daur ulang gel agarose ini lebih sederhana. Gel agarose daur ulang disimpan dalam plastik dan dimasukkan dalam kulkas suhu $4^{\circ} \mathrm{C}$. Jika akan digunakan kembali gel agarose dipotong kecil-kecil dimasukkan dalam elermeyer. Setiap volume $100 \mathrm{ml}$ gel agarose ditambahkan larutan buffer TBE $1 \mathrm{x}$ sebanyak $1 \mathrm{ml}$. Penambahan buffer ini berfungsi untuk mempertahankan konsentrasi agarose agar tetap stabil pada waktu dipanaskan. Penelitian ini menggunakan floro few sebagai pewarna floresen dan ditambahkan $2,5 \mu \mathrm{l}$ kosentrasi $10 \mathrm{mg} / \mathrm{ml}$ (setengah dari konsentrasi gel agarose baru) pada setiap pembuatan $100 \mathrm{ml}$ daur ulang gel agarose. Metode daur ulang gel agarose ini dinilai lebih efisien karena tidak perlu lagi menimbang agarose dan menghemat pemakaian agarose baru serta mengurangi limbah laboratorium.

\section{PENUTUP}

\section{Kesimpulan}

Berdasarkan hasil penelitian dapat disimpulkan sebagai berikut:

1. Daur ulang limbah gel agarose dapat digunakan untuk tujuan efisiensi reagen elektroforesis.
2. Daur ulang limbah gel agarose dapat digunakan 1-4 kali ulangan untuk efisiensi reagen elektroforesis.

3. Daur ulang limbah gel agarose sebanyak 1 kali akan memberikan hasil terbaik untuk efisiensi reagen elektroforesis.

\section{Saran}

Dapat dilakukan penelitian tentang daur ulang limbah gel agarose menggunakan metode dan parameter yang lain.

\section{DAFTAR PUSTAKA}

Bruce, A., D. Bray., J. Lewis, M. Raff., Roberts dan J.D. Watson, 1994 Biologi Molekuler Sel Mengenai Sel. Jakarta: PT. Gramedia Pustaka Utama.

Fatchiyah, Estri Laras Arumyngtias, Sri Widyarti, Sri Rahayu, 2011, Biologi Molekular Prinsip Dasar Analisis. Jakarta: Erlangga.

Mary Ann Liebert, Inc, 2013, DNA and Cell Biology. Published in Volume: 32 Issue 6

Muhammad Ridwan Harahap, 2018, Elektroforesis: Analisis Elektronika Terhadap Biokimia dan Genetika, Jurnal IImiah Pendidikan Teknik Elektro, Vol.2, No.1 hal. 21-26 ISSN: 2549.

Noboru Sasagawa, 2018, A freeze-andthaw method to reuse agarose gels for DNA electrophoresis, BioScience Trends; 12(6):627629.

Palacios G, Giménez C, García ED, 2000, Recycling agarose. Plant Mol Biol Rep. 18:47-4

Sudjadi. (2008), Bioteknolgi Kesehatan, Yogyakarta: Kanisius.

Triwibowo Yuwono, (2009), Biologi Molekular, Jakarta: Erlangga. 